\title{
Biologi Reproduksi dan Polinasi Buatan Tumbuhan Senduduk (Melastoma malabathricum L.)
}

\section{Biology Reproduction And Artificial Polination of Senduduk (Melastoma malabathricum L.)}

\author{
Lilis Suryani \\ Program Studi Biologi, Universitas Mohammad Natsir, Bukittinggi \\ Email : suryanililis@umnyarsi.ac.id
}

\begin{abstract}
Melastoma malabthricum is the type with the widest area of spread compared with other species in the genus Melastoma. This research uses floral phenology observation method and pollination experiment by using bagging technique, emasculation and artificial pollination. Stigma receptivity was tested according to the Matson method. The results showed that M. malabathricum's flowers take 14 until 21 days from bud to flower bloom. Stigma M. malabathricum is already present and receptive before anthesis flower. Fruit can be formed through self pollination (autogamy) and cross pollination (xenogamy). M. malabathricum pollination approaches the xenogamy facultative.
\end{abstract}

Keywords : Anthesis, pollination, xenogamy.

\section{PENDAHULUAN}

Tumbuhan M. malabathricum merupakan jenis tumbuhan dengan area penyebaran yang paling luas dibandingkan dengan jenis-jenis lain dari genus Melastoma. Individu $M$. malabathricum banyak tumbuh di pinggir jalan, pinggir sungai, hutan sekunder, lahan kosong yang belum ditanami atau padang rumput sampai ketinggian 2900 mdpl. Penyebaran jenis ini sangat berbeda dengan dengan jenis Melastoma lainnya, misalnya M. montanum merupakan endemik di New Guinea, M. beccarianum merupakan spesiasi allopatrik di Kalimantan, M. minahassae dan $M$. perakense hanya ditemukan di daerah pegunungan (Meyer, 2001).

Tumbuhan M. malabathricum yang dikenal dengan senduduk atau sikaduduak (Minang); harendong (Sunda); kluruk, senggani (Jawa), mempunyai beberapa manfaat dian-taranya daun dan buahnya dapat dimakan, akar dan daun tanaman ini digunakan sebagai obat disentri, obat wasir dan akarnya sebagai pembersih mulut (saat sakit gigi), buahnya dapat sebagai pewarna dan bunganya sebagai hiasan dan dekorasi (Burkill, 1966). M. malabathricum juga dike-tahui memiliki potensi sebagai alelopati karena beberapa alelokimia seperti senyawa terpenoid, flavonoid dan fenolik ditemukan dalam senyawa yang diisolasi (Faravani, Baki, dan Khalijah, 2008).

Penyerbukan adalah suatu peristiwa perpindahan serbuk sari dari anthera ke stigma (Woodland, 1997). Sistem polinasi pada $M$. malabathricum belum banyak dikaji. Polinasi M. malabathricum dibantu oleh lebah (Meyer, 2001). Besarnya variasi morfologi dan luasnya distribusi jenis ini pada berbagai habitat diduga berkaitan dengan sistem polinasi. Sehubungan dengan permasalah tersebut, maka akan dilakukan penelitian tentang sistem polinasi pada bunga M. malabathricum.

\section{METODOLOGI PENELITIAN}

Penelitian dilakukan dengan metode observasi perkembangan bunga dan percobaan polinasi dengan menggunakan teknik bagging, emaskulasi dan polinasi buatan dari bunga 
M. malabathricum. Reseptivitas stigma diuji menurut metode Matson.

Untuk pengamatan fenologi bunga, ditentukan individu yang memenuhi syarat untuk pengamatan ini yaitu bunga atau batang yang sehat dan mempunyai kuncup bunga yang kecil (Dafni, 1992). Kemudian diberi label, selanjutnya dilakukan pengukuran setiap hari terhadap kuncup bunga hingga bunga mekar. Juga dilakukan pengamatan kapan anthera pecah dan uji reseptivitas stigma. Dengan diketahuinya pola perbungaan maka hal tersebut diperlukan untuk percobaan polinasi. Beberapa perlakuan dilakukan untuk mengetahui sistem polinasi dari M. Malabathricum seperti polinasi alami dan polinasi buatan

Percobaan polinasi alami diberikan perlakuan sebagai berikut : 1) Bunga dibiarkan terbuka (non bagging) sebagai kontrol. 2) Bunga sebelum anthesis ditutup (bagging). Hal ini dilakukan untuk mengetahui apakah bunga $M$. malabathricum dapat melakukan polinasi sendiri (self pollination) atau polinasi silang (cross pollination). 3) Bunga diemaskulasi dengan cara membuang organ reproduksi jantan, setelah itu bunga ada yang dibungkus dan ada yang dibiarkan terbuka. Hal ini dilakukan untuk mengetahui apakah buah dapat terbentuk tanpa adanya polinasi. Masing-masing perlakuan disediakan 30 bunga, kemudian dilakukan pengamatan sampai terbentuk buah. Induksi keberhasilan pembentukan buah dari perlakuan tersebut diamati dari gugurnya perianthium, sedangkan kegagalan pembentukan buah diamati dari gugurnya bunga. Sebagai pendukung diamati setiap serangga yang mengunjungi bunga.
Percobaan polinasi buatan dilakukan persilangan sebagai berikut: 1) Persilangan antara bunga yang berbeda pada individu yang sama (geitonogamy). 2) Persilangan antara bunga pada individu yang berbeda (xenogamy). Untuk persilangan xenogamy digunakan polen dari stamen panjang dan stamen pendek. Masing masing persilangan disediakan 30 bunga, sebelumnya pada masing masing bunga dilakukan emaskulasi agar bunga tidak dapat melakukan polinasi sendiri. Setelah itu bunga ditutup (bagging) agar tidak mendapat gangguan dari luar, kemudian diamati sampai terbentuk buah.

\section{HASIL DAN PEMBAHASAN}

Bunga M. malabathricum berupa bunga majemuk panicle atau malai. Bunga majemuk terdapat pada cabang pertama. Bunga terdapat di ujung (terminalis). Berdasarkan posisi dan kedudukan bunga diketahui bahwa bunga mulai mekar dari bagian paling atas dan diikuti oleh bunga di bawahnya (Gambar 1).

Bunga monoceus, dimana pada satu individu terdapat bunga jantan dan bunga betina. Bunga biseksual, dimana pada satu tangkai bunga terdapat organ reproduksi jantan (androceum) dan organ reproduksi betina (gynaceum). Bunga $M$. malabathricum merupakan bunga yang lengkap terdiri dari tangkai bunga (pedisel), kelopak (calyx), mahkota (corolla), dan organ reproduksi. bunga terdiri atas sumbu dimana terdapat organ-organ bunga yang lain tumbuh (Fahn, 1982).

Bagian dari sumbu yang merupakan ruas yang berakhir dengan bunga disebut pedisel. Ujung pedisel ini menggembung dengan panjang yang beragam disebut reseptakel. 
Organ-organ bunga melekat pada reseptakel. Organ yang paling luar adalah sepal yang secara bersamasama membentuk calyx. Di sebelah dalam sepal adalah corolla yang terdiri atas petal. Kedua jenis organ ini bersama-sama membentuk perhiasan bunga. Di dalam perhiasan bunga ditemui dua macam organ reproduksi, yang sebelah luar disebut stamen yang bersama-sama membentuk androceum, dan sebelah dalam disebut karpel yang membentuk gynaceum.

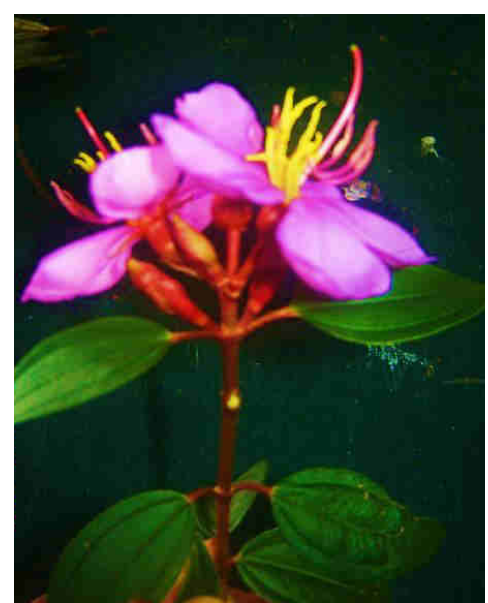

Gambar 1 : Tipe Bunga Majemuk dan Pola Percabangan M. malabathricum.

Stamen pada M. malabathricum (Gambar 2) terdiri dari kepala sari (anther) yang disusun oleh kantong polen dan terletak pada satu tangkai yang disebut filamen. Stamen terletak mengelilingi bagian dasar ovari dan berjumlah sepuluh. M. malabathricum mempunyai dua macam stamen berbeda yaitu stamen panjang berwarna ungu sebanyak lima buah dan stamen pendek berwarna kuning sebanyak lima buah. Kesepuluh stamen ini tersusun selang-seling.

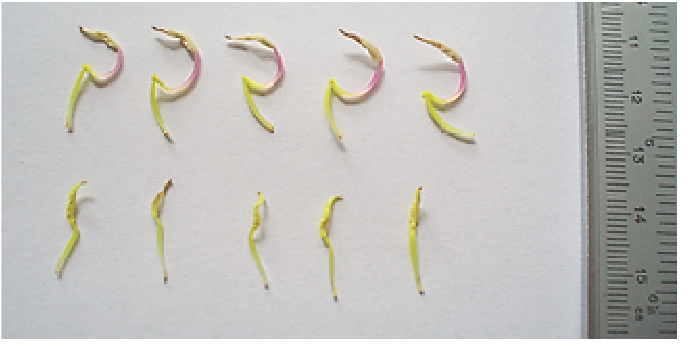

Gambar 2 : Stamen pada M. malabathricum, Stamen Panjang (atas), Stamen Pendek (bawah).

Pollen (serbuk sari) terdapat dalam anther yang pecah pada saat bunga mekar. Polen berjumlah sangat banyak. Keberadaan polen sangat berperan pada keberhasilan penyerbukan. Semakin besar jumlah polen maka semakin besar kemungkinan untuk terjadinya penyerbukan (Cruden, 1976). Polen pada $M$. malabathricum berukuran 26-29,7 $\mu \mathrm{m}$. Berdasarkan ukurannya polen pada $M$. malabathricum ini termasuk tipe media yaitu polen dengan ukuran 25$50 \mathrm{\mu m}$. Pengelompokkan polen berdasarkan panjang diameter sebagai berikut : perminuta, diameternya kurang dari $10 \mu$; minuta, 10-25 $\mu$; media, 25-50 $\mu$; magna, 50-100 $\mu$; permagna 100-200 $\mu$; giganta, diameternya lebih dari $200 \mu$ (Erdtman, 1952). Polen pada M. malabathricum memiliki tiga apertur dengan tipe trikolpata. Fahn (1982), membedakan antara tipe-tipe aperture pada pollen, empat diantaranya yaitu sulkus, kolpa, ruga dan porus.

Biji sangat banyak yang terletak di dalam daging buah. Biji berbentuk seperti kerang. Berdasarkan karakter jumlah lokus ovari dan biji, Keng (1976), mengelompokkan melastomataceae atas tiga sub famili yaitu: 1) Sub famili astroniodeae, ovari terdiri dari 2 sampai banyak lokus. 2) Sub famili memecyloideae, ovari terdiri dari 1 sampai 6 lokus. 3) Sub famili melastomatoideae, ovari terdiri 
dari 2 sampai 5 lokus. Berdasarkan pembagian sub famili menurut Keng, maka M. malabathricum termasuk ke dalam kelompok sub famili Melastomatoideae dengan jumlah lokus ovari sebanyak 5 lokus.

Ada lima tahap perkembangan bunga yang diamati pada penelitian ini yaitu: 1) kuncup kecil, pada tahap ini petal belum kelihatan. 2) kuncup besar, pada tahap ini petal telah terlihat tapi belum membuka. 3) bunga mulai mengembang. 4) bunga mekar sempurna (anthesis) 5) bunga layu (Dafni, 1992). Dari lima tahap perkembangan bunga $M$. malabathricum yang diamati pada 10 individu didapatkan bahwa proses pemekaran bunga pada masingmasing individu bervariasi (Gambar 3).

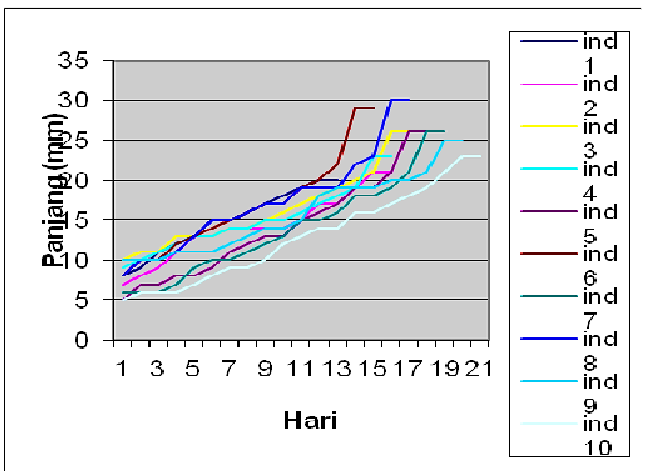

Gambar 3 : Pertumbuhan Bunga M. malabathricum.

Dari hasil pengamatan menunjukkan bahwa pada satu kuncup bunga, yang lebih dahulu terlihat berkembang adalah braktea yang menutupi organ-organ yang terletak di dalam bunga. Pada satu tangkai bunga majemuk dijumpai beberapa kuncup bunga dan mekarnya dimulai dari kuncup yang paling atas dan diikuti oleh kuncup lain dibawahnya, model perkembangan bunga yang seperti ini menurut Darjanto dan Satifah (1987), disebut sebagai perkembangan bunga yang terbatas (inflorescentia cymosa).

Pada masing-masing bunga terdapat dua sampai tiga braktea. Seiring dengan pertumbuhan kuncup, braktea ini ada yang gugur dan ada yang tetap bertahan sampai stadium kuncup kecil. Pada braktea yang tidak gugur ada yang membuka dan ada yang tetap menempel pada bagian hypantium bunga. Stadium kuncup kecil (Gambar 4a) berlangsung lebih lama dibandingkan dengan tahap perkembangan bunga yang lain. Pada masing-masing individu yang diamati mempunyai waktu yang berbeda-beda pula untuk tahap kuncup kecil ini. Rata-rata lama waktu pertumbuhan kuncup kecil adalah 9 sampai 16 hari dengan panjang kuncup berkisar antara 5 sampai $17 \mathrm{~mm}$. Pada stadium kuncup besar (Gambar 4b), petal sudah mulai muncul tapi belum mengembang. Pada tahap ini, pertambahan panjang kuncup berlangsung sangat cepat yaitu 18 sampai 26 mm selama 3 sampai 5 hari. Pada beberapa kuncup, pistilumnya sudah ada yang kelihatan. Hal ini memungkinkan terjadinya penyerbukan silang.

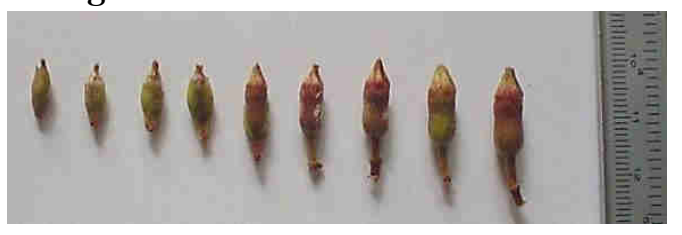

Gambar 4a : Stadium Kuncup Kecil

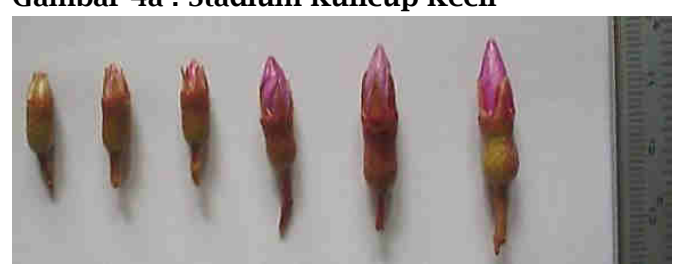

Gambar 4b : Stadium Kuncup Besar

Setelah kuncup bunga mengalami pemekaran sempurna (Gambar 5), tidak terjadi lagi pertumbuhan bunga. 
Mekarnya bunga didahului dengan membukanya keseluruhan petal dengan cara memutar. Proses mekarnya bunga berlangsung lebih kurang 2 jam, biasanya terjadi pada pagi hari. Setelah petal membuka, stamen mulai muncul satu persatu, didahului oleh stamen panjang lalu diikuti oleh stamen pendek, anthera membuka dan polen keluar dari anthera. Polen ada yang menempel pada petal dan kemungkinan ada yang diterbangkan angin lalu menempel ke stigma.

Posisi stigma yang lebih tinggi dari stamen memungkinkan untuk terjadinya penyerbukan silang. Penyerbukan sendiri dapat juga terjadi karena pada saat bunga mekar, beberapa serangga hinggap pada bunga seperti lebah dan semut.

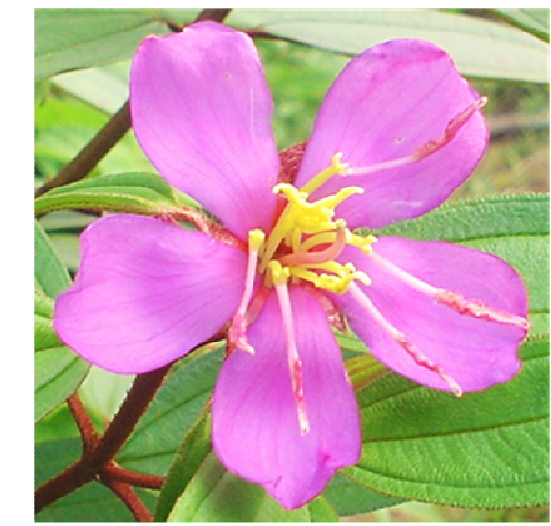

Gambar 5 : Bunga M. malabthricum pada Saat Mekar Sempurna

Menurut Darjanto dan Satifah (1987), lebah mendatangi bunga pada saat bunga-bunga mulai mekar di waktu pagi hari. Selain untuk mencari nektar, lebah mendatangi bunga untuk mendapatkan serbuk sari yang mengandung lemak dan protein. Pada umumnya lebah hanya mendatangi satu jenis tanaman yang sedang berbunga lebat berulang kali. Setelah bunga mekar sempurna, bunga dapat bertahan selama 1-2 hari.

Keberhasilan polinasi ditentukan oleh reseptivitas stigma dan saat pecahnya anther untuk mengeluarkan polen. Pada penelitian ini umumnya stigma sudah reseptif yang ditandai dengan stigma berlendir, terjadi pada saat bunga dalam stadium kuncup besar sampai 2 atau 3 hari setelah bunga mekar. Stigma pada M. Malabathricum tergolong ke dalam tipe stigma basah dimana permukaan stigma ditutupi oleh cairan sekresi pada saat reseptif. Namun uji reseptivitas stigma sehari sebelum mekar, stigma telah reseptif pada saat bunga masih kuncup sedangkan pada saat yang sama anthera belum pecah (Tabel 1). Dengan demikian tumbuhan ini bersifat protogini yaitu stigma reseptif lebih awal dibandingkan dengan pelepasan polen.

Tabel 1 : Pengamatan Reseptivitas Stigma.

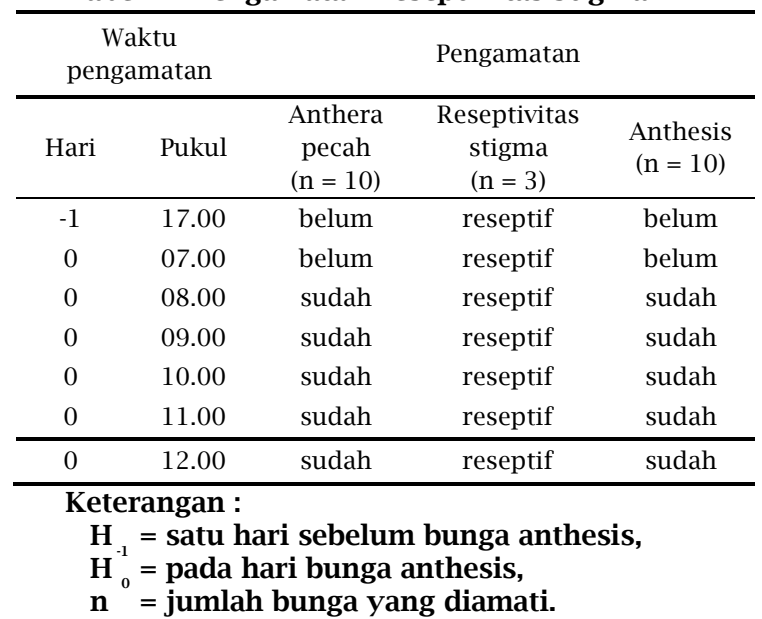

Bunga layu didahului dengan terjadinya perubahan warna pada perhiasan bunga. Stadium ini berlangsung 1-2 hari setelah bunga mekar. Warna keseluruhan bunga dan stamen secara perlahan-lahan berubah menjadi kecoklatan dan akhirnya gugur. Pada saat bunga gugur, ada pistilum yang juga ikut gugur tetapi ada juga pistilum yang masih tetap bertahan, mengalami perubahan warna baru kemudian gugur. 
Pada bunga M. malabathricum yang mengalami penyerbukan, hypanthium akan membesar sehingga terbentuk buah. Setelah masak buah akan pecah. Mulai munculnya kuncup bunga hingga membentuk buah masak sempurna memerlukan waktu lebih kurang 1,5-2 bulan.

Dari percobaan polinasi yang telah dilakukan didapatkan hasil seperti tabel 2. Pada perlakuan bunga dibungkus, jumlah terbentuk buah lebih sedikit yaitu sebesar $36,67 \%$ dibandingkan dengan perlakuan bunga yang tidak dibungkus yaitu sebesar 83,33\%. Dengan ini dapat diketahui bahwa bunga M. malabathtricum dapat melakukan penyerbukan sendiri walaupun persentasenya lebih kecil dibanding bunga dengan perlakuan tidak dibungkus. Perlakuan bunga yang tidak dibungkus (polinasi alami) menunjukkan persentase terbentuknya buah lebih tinggi, hal ini disebabkan adanya polinator dan beberapa serangga yang datang.

Pada perlakuan emaskulasi bunga yang dibuka dan ditutup tidak satupun dari bunga yang diamati dapat menghasilkan buah. Dengan ini dapat kita ketahui bahwa pada bunga M. malabathtricum tidak dapat membentuk buah tanpa adanya penyerbukan dan polinasi tidak terjadi tanpa adanya polen. Ini membuktikan bahwa M. malabathricum tidak termasuk tumbuhan yang partenokarpi yaitu tumbuhan yang dapat membentuk buah tanpa adanya penyerbukan atau pembuahan Darjanto dan Satifah, 1987).

Pada percobaan polinasi sendiri (autogami), didapatkan hasil terbentuknya buah sebesar 73,33\%, lebih banyak dibandingkan dengan polinasi silang (xenogami) yang hanya $60 \%$. Jumlah terbentuknya buah pada poli- nasi sendiri lebih sedikit dibandingkan dengan jumlah buah yang terbentuk pada percobaan polinasi alami (non bagging). Pada percobaan polinasi xenogami disilangkan polen dari stamen panjang dan stamen pendek. Didapatkan hasil persilangan stamen panjang lebih banyak terbentuk buah yaitu sebesar 60\% dibandingkan polen yang berasal dari stamen pendek sebesar 33,3\%.

\begin{tabular}{|c|c|c|c|}
\hline $\begin{array}{c}\text { Tipe } \\
\text { Polinasi }\end{array}$ & Jumlah & $\begin{array}{c}\text { Percobaan } \\
\text { polinasi }\end{array}$ & $\begin{array}{c}\text { Terbentuk } \\
\text { buah } \\
\text { (\%) }\end{array}$ \\
\hline \multirow{3}{*}{$\begin{array}{l}\text { Polinasi } \\
\text { alami }\end{array}$} & 30 & kontrol & 83,3 \\
\hline & 30 & emaskulasi & 0,0 \\
\hline & 30 & $\begin{array}{c}\text { Autogami } \\
\text { (bagging) }\end{array}$ & 36,7 \\
\hline \multirow{3}{*}{$\begin{array}{l}\text { Polinasi } \\
\text { buatan }\end{array}$} & 30 & $\begin{array}{l}\text { Geitonogami } \\
\text { (selfing) }\end{array}$ & 73,3 \\
\hline & 30 & $\begin{array}{c}\text { Xenogami } \\
\text { (outcrossing) } \\
\text { stamen pan- } \\
\text { jang }\end{array}$ & 60,0 \\
\hline & 30 & $\begin{array}{c}\text { Xenogami } \\
\text { (outcrossing) } \\
\text { stamen pen- } \\
\text { dek }\end{array}$ & 33,3 \\
\hline
\end{tabular}

\section{KESIMPULAN}

Berdasarkan pengamatan yang dilakukan terhadap M. malabathricum, diketahui tumbuhan bersifat protogini. Proses perkembangan bunga dari kuncup hingga bunga mekar pada masing-masing individu $M$. malabathricum bervariasi yaitu 14-21 hari dan stigma sudah ada yang muncul dan sudah reseptif sebelum bunga anthesis.

Buah dapat terbentuk melalui polinasi sendiri maupun polinasi silang. Persilangan dengan menggunakan stamen pendek berhasil membentuk buah sebesar 33,3\%. Polinasi $M$. malabathricum mendekati fakultatif xenogami. 



\section{DAFTAR PUSTAKA}

Cruden, R. W. 1976. Pollen-Ovule Ratios: A Conservative Indicator of Breeding System in Flowering Plants, (March 1976), 32-46.

Dafni, A. 1992. Pollinators Ecology A Practical Approach. New York: Oxford University Press.

Erdtman, G. 1952. Pollen Morphology and Plant Taxonomy: Angiosperms. Chronica Botanica, Waltham. Mass.

Fahn, A. 1982. Anatomi Tumbuhan. Yogyakarta: Gajah Mada University Press.

Faravani, M., Baki, H. B., Khalijah, A. 2008. Assessment of Allelopathic Potential of Melastoma malabathricum L. on Radish raphanus sativus L. and Barnyard Grass (Echinochloacrus galli). Notulae Botanicae Horti Agrobotanici Cluj-Napoca, 36(2), 54-60.

Keng, H. 1976. Ordes and Families of Malayan Seed Plants. Singapura: Singapore University Press.

Meyer, K. 2001. Revision of The Southeast Asian Genus Melastoma (Melastomataceae).

Satifah, S. dan D. 1987. Pengetahuan Dasar Biologi Bunga dan Teknik Penyerbukan Silang Buatan. Jakarta: PT Gramedia.

Woodland, D. W. 1997. Contemporary Plants Systematics (Second edi). United State of America: Berrien Springs Michigan. 